\title{
Petrological and geochemical snapshot \\ of a melt-rich crystal mush: The 289 ka Fasnia eruption, Tenerife
}

\author{
EMMA L HORN ${ }^{1}$, REX N TAYLOR ${ }^{1}$, THOMAS M \\ GERNON $^{1}$ AND MICHAEL J STOCK ${ }^{2}$ \\ ${ }^{1}$ University of Southampton \\ ${ }^{2}$ Trinity College Dublin \\ Presenting Author: e.1.horn@soton.ac.uk
}

Understanding the composition of, and relationships between, melt and crystals through the vertical extent of a magmatic system is important in developing models of pre-eruptive magma assembly prior to large, explosive eruptions. The 289 ka Fasnia eruption on Tenerife ejected cumulate mush nodules, which provide a unique opportunity to examine the architecture and dynamics of such a system. We have analysed over 100 cumulate samples from this event, ranging from ultramafic wehrlite and clinopyroxenite, through hornblende gabbros, to felsic monzonite and syenite. These appear to span the complete crystallisation pathway of this alkaline magma system. All of the cumulate types contain interconnected and interstitial melt that quenched during the eruption, and we calculate that the magmatic system contained $\sim 21 \%$ melt immediately prior to eruption. Petrological analysis indicates that the cumulates originate from a reservoir with three distinct domains: a mafic zone, a layered gabbroic sequence and a felsic zone. However, cumulus phases record the interaction between felsic and mafic magmas at different stages of their development, for example through felsic compositions recorded in relic cores and rims of cumulus clinopyroxene grains. Multiple crystallisation histories and diverse cumulate textures developed on a local scale and reveal a highly heterogeneous mush pile. Tenerife eruptions between 350-200 ka produced phonolite volcanic products which are compositionally distinct from other deposits on the island, with low bulk-rock and matrix glass $\mathrm{Nb}$ relative to $\mathrm{Zr}$, high $\mathrm{La} / \mathrm{Sm}$ and elevated $\mathrm{Al}_{2} \mathrm{O}_{3}$. Interstitial melts separated from the Fasnia cumulates are predominantly basanitic but extend through basaltic trachyandesite to a trachyte. Overall, these melts define a trend extending to lower total alkalis and higher $\mathrm{Al}_{2} \mathrm{O}_{3}$ at a given $\mathrm{SiO}_{2}$ than observed in Tenerife deposits between 350 and $200 \mathrm{ka}$, and are consistent with crystallisation models containing a lower proportion of plagioclase. These characteristics, combined with the highly MREE-depleted compositions of Fasnia and other 350-200 ka phonolitic pumices, are indicative of plagioclasepoor, hornblende-rich, $\mathrm{H}_{2} \mathrm{O}$-rich magmatism during this interval. Indeed, some of the largest volume explosive eruptions on Tenerife occurred during this time. This may be linked to high fluxes of hydrous magmas supplied by the Canary mantle plume. 